\title{
Morinda citrifolia Leaf Enhances In Vitro Osteogenic Differentiation and Matrix Mineralization by Human Periodontal Ligament Cells
}

Kanitsak Boonanantanasarn, Kajohnkiart Janebodin*, Prapan Suppakpatana, Tawepong Arayapisit, Panjit Chunhabundit, Jit-Aree Rodsutthi, Orapin Termvidchakorn and Wanida Sripairojthikoon

Department of Anatomy, Faculty of Dentistry, Mahidol University, Thailand

\begin{abstract}
Morinda citrifolia L. (noni) has been reported to have a variety of potentially therapeutic effects such as antibacterial, antiviral, antifungal, antitumor, antihelmin, analgesic, hypotensive and anti-inflammatory, as well as immune enhancing properties. In this study, we aimed to investigate a potential effect of Morinda citrifolia leaf aqueous extract to induce osteogenic differentiation and matrix mineralization of human periodontal ligament (hPDL) cells in vitro. The optimal biocompatible dose of noni leaf aqueous extract was determined by a cell proliferation assay. The hPDL cells were cultured in growth medium alone, or medium supplemented with noni leaf aqueous extract, or $\beta$-glycerophosphate and ascorbic acid. The early osteogenic differentiation marker, alkaline phosphatase activity, was assayed using a biochemical analysis. Matrix mineralization was examined after 6 weeks in vitro by calcium staining and energy dispersive x-ray analysis. The noni leaf aqueous extract group significantly increased alkaline phosphatase activity, compared to either growth medium alone or $\beta$-glycerophosphate and ascorbic acid groups. Nodules containing mineralized matrices were formed only when the hPDL cells were cultured in the presence of noni leaf aqueous extract. These nodules were positively stained with Alizarin Red and were rich in calcium and phosphorus as revealed by the energy dispersive $\mathrm{x}$-ray analysis. These data indicate the potential effect of noni leaf aqeous extract to promote osteogenic differentiation as well as matrix mineralization in hPDL cells and suggest that noni leaf has therapeutic benefits in bone and periodontal tissue regeneration.
\end{abstract}

Keywords: Morinda citrifolia; Noni; Osteoblast; Mineralization; Human periodontal ligament cells

\section{Introduction}

Periodontitis is a chronic infectious disease of the periodontium affecting children, adolescents, adults, and the elderly, and is characterized by irreversible loss of connective tissue attachment and supporting alveolar bone [1]. Restoration of damaged periodontal tissue requires a combination of cells, signaling molecules such as those found in osteoinductive materials, and osteoconductive scaffolds. Growth factors modulate the cellular activity and provide stimuli to cells to differentiate and create extracellular matrices for the developing tissue. Scaffolds guide and create a template structure to facilitate the above processes, which is critical for tissue regeneration [2]

Periodontal ligament (PDL) is a lining connective tissue located between cementum and alveolar bone and functions to sustain and constrain teeth within the jaw. This unmineralized tissue contains PDL cells which play an integral role in maintenance, repair and regeneration of periodontal tissue [3]. These PDL cells are heterogeneous, consisting of several cell types including fibroblasts and mineralized tissue forming cells such as osteoblasts and cementoblasts [4-6].

Several studies demonstrated that cells isolated from PDL have osteoblast and cementoblast-like properties. For example, PDL cells produce type I collagen and non-collagenous extracellular matrix proteins such as osteopontin and bone sialoprotein in vitro $[7,8]$ as well as the expression of bone-associated markers, alkaline phosphatase (ALP) under bone inductive factors, such as parathyroid hormone, insulin-like growth factor, bone morphogenic proteins, 1,25-dihydroxyvitamin $\mathrm{D}_{3}$ [8-12]. In addition, PDL cells are capable of forming bone-like and/or cementum-like mineralized nodules when cultured in a medium containing ascorbic acid and dexamethasone $[13,14]$.

Various potential osteoconductive and osteoinductive materials have been suggested to promote the regeneration of alveolar bone and periodontal attachment $[15,16]$. However, several growth factors are mostly capable of inducing PDL cell proliferation or migration $[17,18]$. Therefore, many osteoinductive materials have been extensively evaluated in order to obtain the inducing osteogenic differentiation and mineralization with low cost for periodontal tissue regeneration.

Morinda citrifolia is one of the traditional folk medicinal plants in Polynesia, and Southeast Asia, also known as noni. The major components of the whole noni plant have been found such as scopoletin, octoanoic acid, potassium, ascorbic acid (vitamin C), terpenoids, alkaloids, anthraquinones, $\beta$-sitosterol, carotene, retinoic acid (vitamin A), flavone glycosides, linoleic acid and amino acids, including calcium and phosphorus $[19,20]$. Noni has been reported for a broad range of usage including antibacterial, antiviral, antifungal, antitumor, antihelmin, analgesic, hypotensive, anti-inflammatory, and immune enhancing effects [19,21-23].

The primary usage of noni is to apply leaves as a traditional topical treatment thought to enhance wound healing. Noni leaf extract was capable of promoting wound healing in an animal model [24]. In addition, the crude extract of noni leaf has been traditionally used in patients with bone fractures or dislocation to promote tissue repair and decrease inflammation [19]. It is well established that bone and periodontal tissue repair or regeneration requires growth factors to induce progenitor/precursor cells to differentiate and produce matrix

*Corresponding author: K. Janebodin, D.D.S., 6 Yothi Street, Rajthevi Department of Anatomy, Faculty of Dentistry, Mahidol University, Bangkok 10400 Thailand, E-mail: dtjanebk@uw.edu

Received January 30, 2012; Accepted March 26, 2012; Published March 28 2012

Citation: Boonanantanasarn K, Janebodin K, Suppakpatana P, Arayapisit T, Chunhabundit P, et al. (2012) Morinda citrifolia Leaf Enhances In Vitro Osteogenic Differentiation and Matrix Mineralization by Human Periodontal Ligament Cells. Dentistry 2:130. doi:10.4172/2161-1122.1000130

Copyright: (c) 2012 Boonanantanasarn K, et al. This is an open-access article distributed under the terms of the Creative Commons Attribution License, which permits unrestricted use, distribution, and reproduction in any medium, provided the original author and source are credited. 
mineralization [2]. Nevertheless, there is no experimentally supporting evidence for the healing activities of noni extracts on bone or osteogenic differentiation in the literature. The present study, therefore, investigated the osteoinductive potential of the noni leaf extract on human PDL (hPDL) cells, focusing on in vitro alkaline phosphatase (ALP) activity and matrix mineralization as indicators of osteoblastic/ cementoblastic differentiation.

\section{Materials and Methods}

\section{Morinda citrifolia leaf extraction}

Fresh noni leaves were collected from Nakhon Pathom which is a province located in the center part of Thailand, during rainy season (July to October). To obtain $1000 \mathrm{ml}$ of aqueous extract, approximate $1 \mathrm{~kg}$ of fresh leaves were washed with sterilized de-ionized water and blended with $1500 \mathrm{ml}$ of cold sterilized de-ionized water in an electrical blender at medium speed for 1 minute/round. The mixture was repeatedly blended for 10 rounds to get finely chopped contents of herb, and processed the cold infusion by incubation at $4^{\circ} \mathrm{C}$. After 48 hours, the solution was collected, filtered by squeezing through fine gauze and centrifuged at 3,000 rpm for 10 minutes. The supernatant was subsequently filtered through Whatman filter paper no. 1 to remove remaining debris, freeze-dried with a lyophilizer (LYPHLOCK6 Model 77595-01, Labconco, USA) and stored at $-80^{\circ} \mathrm{C}$. The lyophilized noni leaf powder was dissolved in culture medium, filtered through a $0.22 \mu \mathrm{m}$ cellulose acetate filter (Pall Corporation, Michigan, USA), and sterilized by UV light for 30 minutes before experiments.

\section{Cell culture}

Third molar or premolar teeth were obtained from patients aged 17 to 25 years who underwent orthodontic treatments and signed a written informed consent prior to extraction. The experimental protocol was approved by the committee on human rights related to human experimentation, Mahidol University, MU 2007-087. After rinsing several times with Dulbecco's Modified Eagle Medium (DMEM, Gibco BRL, USA) supplemented with $250 \mathrm{IU} / \mathrm{ml}$ penicillin G sodium, $250 \mu \mathrm{g} /$ $\mathrm{ml}$ streptomycin sulfate and $20 \mu \mathrm{g} / \mathrm{ml}$ antimycotic fungizone (Gibco BRL, USA), the periodontal tissues attached to the mid-third of the root were carefully removed with a surgical scalpel, washed twice with phosphate buffered saline (PBS) (Hyclone, USA), and placed in a tissue culture flask. The tissue explants were incubated in growth medium containing DMEM with $10 \%$ fetal bovine serum (Hyclone, USA) and $250 \mathrm{IU} / \mathrm{ml}$ penicillin $\mathrm{G}$ sodium, $250 \mu \mathrm{g} / \mathrm{ml}$ streptomycin sulfate under an environment of $5 \% \mathrm{CO}_{2}$ and $95 \%$ humidified air at $37^{\circ} \mathrm{C}$. The culture medium was changed after 1 week and then every three days until cells grew out of the explants and reached confluence. Cells from passages 3 to 5 were used in these studies.

Mouse calvaria-derived pre-osteoblastic cell line, MC3T3-E1 (a gift from Associate Professor R. Surarit, Department of Physiology and Biochemistry, Faculty of Dentistry, Mahidol University), was cultured under conditions equivalent to those used for hPDL cells.

\section{Cell proliferation assay}

In order to assess the maximum concentration of noni leaf extract which could promote cell growth, the oxidative activity of mitochondria was measured by MTT (3- (4,5-dimethylthiazol-2-yl) -2,5-diphenyltetrazolium bromide) assay [25]. The hPDL cells were seeded at a density of 20,000 cells/well in a 96-well plate (Nunclon, Roskilde, Denmark). After incubation for 24 hours, confluent cells were treated with various concentrations; $0.025,0.625,1.25,2.5$, and
$5 \%(\mathrm{~g} / \mathrm{ml})$ of noni leaf extract diluted in growth medium, at $37^{\circ} \mathrm{C}$ for 24 hours. Cells were washed with PBS and then incubated with $0.05 \%$ MTT (Sigma Co. St. Louis, MO, USA) at $37^{\circ} \mathrm{C}$ for 4 hours with light protection. At the end of the incubation, the untransformed MTT was removed by aspiration and $100 \mu \mathrm{l}$ of DMSO (Dimethysulfoxide, Merck, Darmstradt, Germany) was added to each well to dissolve the formazan crystals. The plate was then shaken vigorously to ensure that the blue formazan was fully solubilized. The optical density (OD) of each well was measured in wavelength mode of $540 \mathrm{~nm}$ using an automatic multi-well microplate spectrophotometer (Maxline Microplate Reader, Molecular Device Corp, Menlo Park, CA, USA). The higher amount of MTT converted to the formazan salt (higher OD) was relative to higher cell proliferation. The percentage of cell proliferation in the treated groups compared to control after 24-hour noni treatment was calculated by the following formula; cell proliferation ( $\%$ of control) $=$ (OD of treated cells/ OD of control cells) x 100.

\section{Alkaline Phosphatase (ALP) Activity Assay}

hPDL cells were seeded at a density of $1 \times 10^{3}$ cells $/ \mathrm{cm}^{2}$ in a 24well plate (Nunclon, Roskilde, Denmark). After 24 hours, the cells were incubated with a) growth medium alone, b) growth medium containing the $2.5 \%(\mathrm{~g} / \mathrm{ml})$ of noni leaf extract that was the highest non-toxic concentration to hPDL cells after 24-hour treatment, or c) growth medium supplemented with $2 \mathrm{mM} \beta$-glycerophosphate $(\beta$ GP) plus $50 \mu \mathrm{g} / \mathrm{ml}$ ascorbic acid. The hPDL cells were cultured for 6 weeks. Each week, the cells from each group were washed with PBS 3 times, collected with a rubber spatula and centrifuged at $1200 \mathrm{rpm}$ for 4 minutes. The precipitate was mixed with $200 \mu$ lof a cold lysis buffer (containing $\mathrm{NaCl}$, EDTA and Triton $\mathrm{X}-100$ in Tris- $\mathrm{HCl}, \mathrm{pH} 7.5$ ) and allowed to lyse at $4^{\circ} \mathrm{C}$. The ALP activity was determined by a modified Lowry method [26,27] and normalized to cellular total proteins to indicate early osteoblastic differentiation.

Total protein of lysed cells was determined with the Bradford protein assay (Sigma, USA) which is a method to measure the concentration of protein based on the formation of a complex between the dye and proteins in solution. The amount of absorption of the dye is proportional to the protein present [28]. Briefly, $5 \mu$ of each suspension sample was added to $250 \mu$ ldye reagent in a 96-well plate, mixed on a shaker for 30 $\mathrm{sec}$, and incubated at room temperature for $30 \mathrm{~min}$. The optical density (OD) for total protein quantification was measured at $595 \mathrm{~nm}$. Bovine serum albumin (BSA) was used as the standard. The amount of protein in the cell lysate samples was calculated by referring to the standard curve. The standard curve was drawn by plotting the concentration of the standard protein solution $(0.25,0.50,0.75,1,1.25$, and 1.50 $\mathrm{mg} / \mathrm{ml}$ of BSA) on the $\mathrm{x}$-axis and the optical density on the $\mathrm{y}$-axis. The protein content in the cell lysate was calculated using the formula; protein concentration $=(\mathrm{OD}$ of sample/OD of standard $) \mathrm{x}$ concentration of standard.

For ALP activity, the reaction was started by adding $20 \mu \mathrm{l}$ suspension of lysed cells to $100 \mu \mathrm{l}$ of $125 \mathrm{mM}$ carbonate-bicarbonate buffer $(\mathrm{pH} 10.3)$ at $37^{\circ} \mathrm{C}$ for 5 minutes, then mixed with $100 \mu \mathrm{l}$ of substrate solution that was composed of $2 \mathrm{mM} \mathrm{MgCl}_{2}$ and $2 \mathrm{mM}$ $p$-nitrophenylphosphate ( $p$-NPP) (Sigma, USA). After incubation at $37^{\circ} \mathrm{C}$ for 15 minutes, the reaction was stopped by adding $100 \mu \mathrm{l}$ of 0.2 $\mathrm{M} \mathrm{NaOH}$. The yellow color of $p$-nitrophenol $(p-\mathrm{NP})$ which is developed from $p$-NPP dephosphorylated by alkaline phosphatase was measured at $405 \mathrm{~nm}$. The $p$-NP standard curve was used to get the amount of $p$-NP generated by ALP sample. The ALP activity was calculated from amount of $p$-nitrophenol generated from total cellular proteins per reaction time and represented as $\mathrm{nmol} / \mathrm{mg}$ protein $/ \mathrm{min}$. 


\section{Mineralized nodule staining}

Following three culture conditions (the growth medium alone, medium supplemented with noni leaf extract, or $\beta$-GP and ascorbic acid) of hPDL cells, nodule formation was observed every week. Alizarin Red staining was used to verify the calcified nodules. After 6 weeks of treatment, cells were washed 3 times with PBS, fixed with ice cold $70 \%$ ethanol for 30 minutes and rinsed with $1 \mathrm{ml}$ of distilled water for 5 minutes to remove ethanol. The cells were then stained with $1 \%$ Alizarin Red solution for 30 minutes, rinsed twice with distilled water, and dehydrated by ethanol series before air dry. The calcified nodules that exhibited bright red color were identified and photographed under an inverted microscope (Nikon Eclipse TS100, Japan) with a digital camera (Nikon Coolpix 4500, Japan).

To confirm the osteogenic induction capacity of noni leaf aqueous extract in other osteogenic precursor cells, MC3T3-E1 cells were incubated with a) complete medium, b) complete medium containing the optimal concentration of noni leaf, or c) complete medium supplemented with $2 \mathrm{mM} \beta$-GP plus $50 \mu \mathrm{g} / \mathrm{ml}$ ascorbic acid. After 6 weeks, matrix mineralization was determined as described above.

\section{Elemental analysis}

Energy dispersive $\mathrm{x}$-ray mapping was done in order to detect the presence of calcium and phosphorus in mineralized nodules. After washing with PBS, the samples were fixed in $2.5 \%$ glutaraldehyde solution for 2 hours at $4^{\circ} \mathrm{C}$. Subsequently, they were frozen by liquid nitrogen, and vacuum-dried immediately in a scanning electron microscope (SEM, JSM-5410LV, Tokyo, Japan). The mineralized nodules were located and subjected to elemental mapping analysis by an Oxford energy-dispersive X-ray spectroscopy (EDS) system (ISIS 300, Oxford instrument, UK) attached to SEM at an accelerating voltage of $20 \mathrm{kV}$.

\section{Statistical analysis}

Three independent experiments were performed. Experimental values in each assay were given as means \pm standard deviation (SD) from triplicate wells. The statistical significance of differences was evaluated by one-tailed Student's $t$ - test for the cell proliferation assay, and one-way ANOVA for the ALP activity. $P$-values less than 0.05 were considered significant using the statistical software (SPSS version 11).

\section{Results}

\section{Effect of noni leaf extract on hPDL cell proliferation}

Cultured hPDL cells exhibited spindle and polygonal morphology regardless of noni leaf extract concentration. In order to assay the effect of noni leaf extract on hPDL cell viability, as well determine as optimal concentration of noni leaf extract for further experiments, a doseresponse experiment employing the MTT assay for cell proliferation was performed. Initially, to establish the range of concentration to use in the MTT assay, the effect of noni leaf extract on hPDL cells was estimated by a 24-hour preliminary experiment of PDL cells treated with noni concentrations from $0.01 \%$ to $10 \% \mathrm{~g} / \mathrm{ml}$. The hPDL cells did not show any alteration when treated by noni leaf extract concentration less than $0.025 \%$; however, cells were completely dead at $7.5 \%$ concentration. Consequently. in this experiment hPDL cells were treated with $0.025 \%$ to $5 \% \mathrm{~g} / \mathrm{ml}$ of noni leaf extract for 24 hours. All concentrations of noni leaf extract, except the highest dose of $5 \%$ $(\mathrm{g} / \mathrm{ml})$, significantly promoted cell proliferation compared to control group levels ( ${ }^{*} p<0.05$ ) (Figure 1 and Table S1). In addition, total protein synthesis in hPDL cells, analyzed by the Bradford protein assay, was affected by all concentrations of noni leaf extract. The $2.5 \%(\mathrm{~g} /$ $\mathrm{ml}$ ) of noni leaf extract is the highest dose in this study that promoted hPDL cell proliferation without any toxicity, and therefore was chosen for use in subsequent experiments.

\section{Noni leaf extract increases alkaline phosphatase activity in hPDL cells}

To examine the effect of noni leaf on osteogenic induction, ALP activity was performed up to the 6 th week. The results showed that the ALP activity of the untreated hPDL cells slowly increased from 5 to 8 $\mathrm{nmol} / \mathrm{mg}$ protein/min need more explanation. The hPDL cells treated with $2.5 \%(\mathrm{~g} / \mathrm{ml})$ of noni leaf extract exhibited about 2 -fold increase in the ALP activity at the end of $2^{\text {nd }}$ week. This enzymatic activity reached the maximum level (4-fold) during the $3^{\text {rd }}$ and $4^{\text {th }}$ weeks, then gradually decreased to a similar level as that of the untreated group at the end of $6^{\text {th }}$ week (Figure 2 and Table S2). In the $\beta$-GP together with ascorbic acid treated group, the ALP activity approximately increased 2 folds during the $2^{\text {nd }}$ and $3^{\text {rd }}$ weeks in comparison with that of cells cultured in the complete medium alone. The ALP activity of the noni treated cells was significantly higher $\left({ }^{*} p<0.05\right)$ than that of the $\beta$-GP together with ascorbic acid treated and untreated groups particularly from the $3^{\text {rd }}$ to the $5^{\text {th }}$ week. These data indicate a potent osteogenic induction of noni leaf extract.

\section{Noni leaf extract increases mineralized matrix formation in hPDL cells}

To confirm the effect of noni leaf extract on hPDL cells, matrix mineralization that correlated with the data of ALP activity was determined for 6 weeks. After 7 days in culture, hPDL cells under all three treatment conditions were spindle-like (Figures 3A-C). Over the course of 6 weeks, hPDL cells cultured with growth medium alone did not form any nodules. Conversely, the formation of cell clusters and small nodules were observed in the noni leaf extract experimental group after 3 weeks (Figure 3D, indicated by an arrow). These nodules gradually increased in size by $4-6$ weeks (Figures $3 \mathrm{E}$ and F). Alizarin Red staining for calcium deposition confirmed that untreated hPDL cells did not form mineralized matrices (Figure 3G). In contrast,

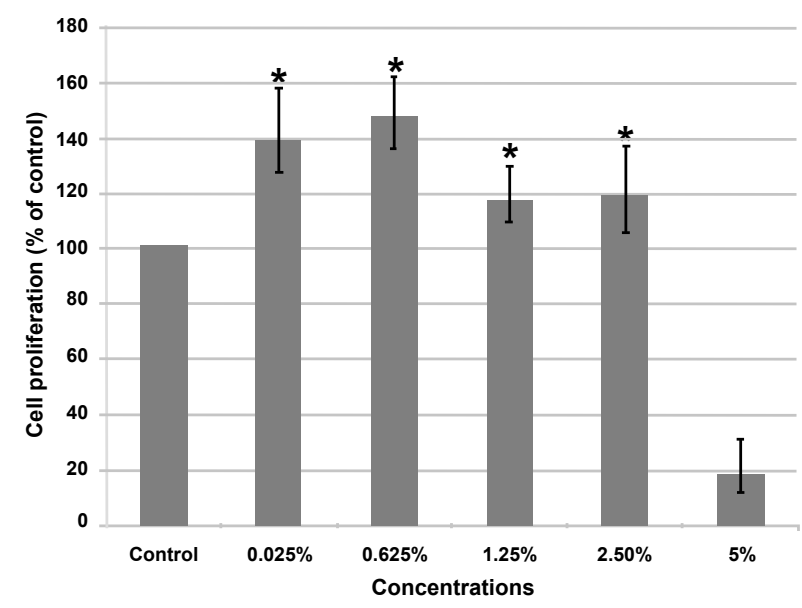

Figure 1: Dose-response effect of noni leaf extract on hPDL cel proliferation. Cell proliferation of $\mathrm{hPDL}$ cells treated with noni leaf extract $(0.025 \%, 0.625 \%, 1.25 \%, 2.5 \%$, and $5 \% \mathrm{~g} / \mathrm{ml})$ for 24 hours was measured by MTT assay. All concentrations of noni leaf extract except $5 \%(\mathrm{~g} / \mathrm{ml})$ significantly enhanced cell proliferation $\left({ }^{*} p<0.05\right)$, compared to the control group. Values are displayed as percentage of control \pm SD from three independent experiments. 
nodules observed in the noni treated hPDL cells were positively stained with Alizarin Red (Figures $3 \mathrm{H}$ and I). The group treated with $\beta$-GP and ascorbic acid formed some cell aggregations with weak Alizarin Red staining after the 6-week experiment (Figure 3J).

\section{Noni Leaf extract enhances mineralized matrix formation in MC3T3-E1 pre-osteoblast cells}

To further examine whether noni leaf extract had a similar effect on mineralized nodule formation in other osteogenic precursor cell types, the murine pre-osteoblast MC3T3-E1 cell line was employed. These cells were treated under conditions similar to hPDL cells. Nodule formation was not detected in the untreated group (Figure $4 \mathrm{~A}$ ). By the $3^{\text {rd }}$ week of culture, mineralized nodules were consistently observed in the group treated by noni leaf extract, and additionally, these nodules were larger (Figure 4B) in comparison to nodules formed in the b-GP and ascorbic acid treated group (Figure 4C). After six weeks, mineralized nodules were still not found in the complete medium treated group (Figure $4 \mathrm{D})$, while progressively larger, Alizarin Red stained nodules were observed in the noni leaf extract treated (Figure 4E), as well as $\beta$-GP with ascorbic acid treated groups (Figure $4 \mathrm{~F}$ ).

\section{Elemental analysis confirms noni-treated hPDL and MC3T3-E1 derived mineralized nodules}

Energy dispersive $\mathrm{x}$-ray mapping under a scanning electron microscope was performed to confirm a composition of mineralized nodules deposited. Elemental analysis indicated that the nodule formation was derived from accumulation of cells and matrices (Figure 5A). Calcium (Figure 5B) and phosphorus (Figure 5C) signals were densely detected in the nodules found in the noni treated group after 6 weeks of treatment.

\section{Discussion}

Bone and periodontal tissue regeneration processes depend upon a sequence of events including cellular proliferation, osteogenic differentiation, and attachment to components of the extracellular matrices together with the organic matrix formation as well as matrix

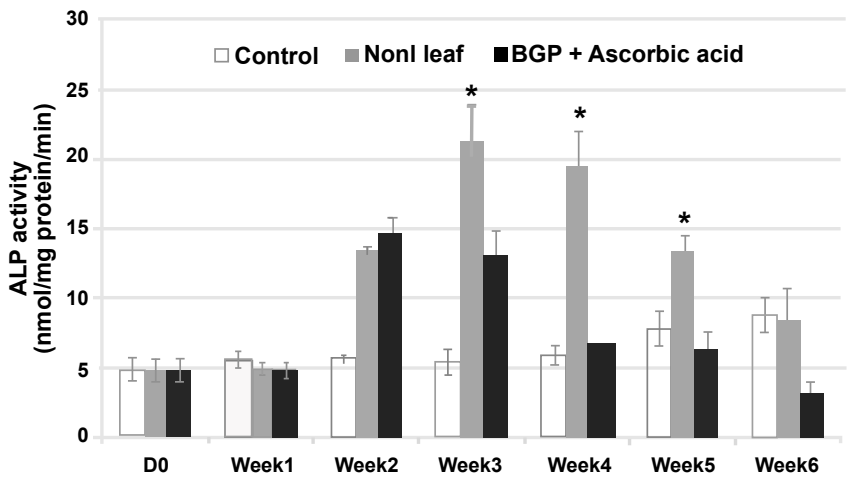

Figure 2: Noni leaf extract increases alkaline phosphatase activity in hPDL cells. ALP activity was measured in hPDL treatment groups over the course of 6 weeks in culture. ALP activity of untreated cells slowly increased over the course of 6 weeks in culture. The hPDL cells treated with $2.5 \%(\mathrm{~g} /$ $\mathrm{ml}$ ) of noni leaf extract demonstrated increased ALP activity at the end of $2^{\text {nd }}$ week, peaking during the $3^{\text {rd }}$ and $4^{\text {th }}$ weeks, before gradually decreasing by the end of $6^{\text {th }}$ week. In the group treated by $\beta$-GP and ascorbic acid, ALP activity approximately increased during the $2^{\text {nd }}$ and $3^{\text {rd }}$ weeks, compared to the untreated group. The ALP activity of noni treated cells significantly increased $\left({ }^{*} p<0.05\right)$, compared to both untreated and $\beta$-GP plus ascorbic acid treated cells, particularly from the $3^{\text {rd }}$ to the $5^{\text {th }}$ week. Values are displayed as mean \pm $\mathrm{SD}$ from three independent experiments.
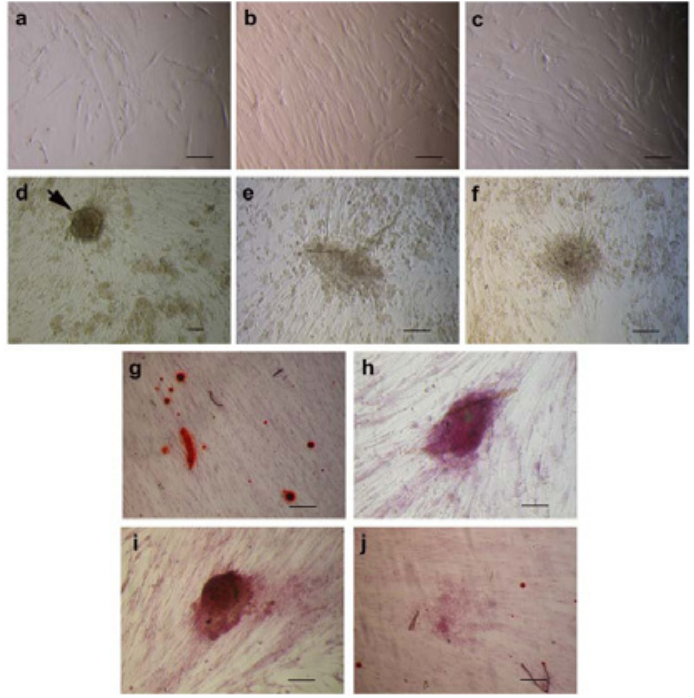

Figure 3: Noni leaf extract increases mineralized matrix formation in hPDL cells. Matrix mineralization was assayed by Alizarin Red staining after 6 weeks in culture. (A-C) Phase-contrast micrographs showed the monolayer of primary hPDL cells with spindle-like morphology after 7 days in culture with complete medium, $2.5 \%(\mathrm{~g} / \mathrm{ml})$ noni leaf extract, or $\beta$-GP together with ascorbic acid, respectively. (D) Formation of a cell cluster associated with a small nodule (indicated by arrow) was observed in the experimental group treated with $2.5 \%(\mathrm{~g} / \mathrm{ml})$ noni leaf extract after 3 weeks. ( $E$ and $F)$ Representative nodules gradually increased in size after 4-6 weeks of the noni leaf extract treatment. (G) hPDL cells cultured in complete medium stained negative for Alizarin Red, indicating that untreated cells did not form mineralized matrix (Note that bright red spots found in the untreated group were an artifact of Alizarin Red precipitation). ( $\mathrm{H}$ and $\mathrm{I}$ ) Mineralized nodules formed by noni-treated hPDL cells were stained strongly positive by Alizarin Red. (J) The $\beta-G P$ with ascorbic acid treated group revealed cell aggregation with only weakly positive Alizarin Red staining after 6 weeks. Scale bars indicate $300 \mu \mathrm{m}$ (D), and $200 \mu \mathrm{m}$ (A-C and E-J).
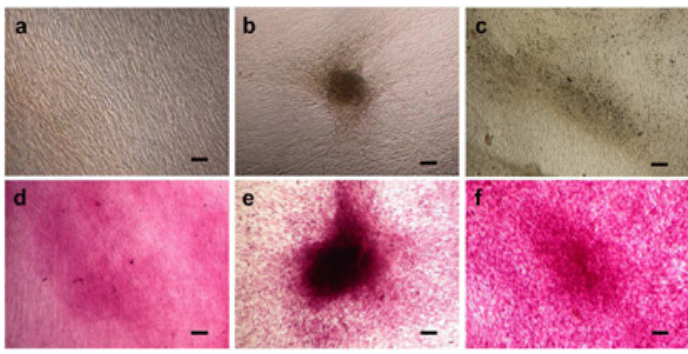

Figure 4: Noni leaf extract increases mineralized matrix formation in MC3T3-E1 pre-osteoblasts. Matrix mineralization was assayed by Alizarin Red staining after 6 weeks in culture. (A) A confluent monolayer of MC3T3-E1 cells was observed in the untreated group without any cellular nodule formation (B and C) Formation of multilayered MC3T3-E1 cells and nodules occurred after 3 weeks with $2.5 \%(\mathrm{~g} / \mathrm{ml})$ noni leaf extract or $\beta-G P$ with ascorbic acid, respectively. (D) Untreated cells remained unstained by Alizarin Red. (E and F) MC3T3-E1 cells treated with noni leaf extract or $\beta-G P$ with ascorbic acid, respectively, produced nodules that stained positively by Alizarin Red. (E) The strongest staining was found in the noni leaf extract group at the end of the culture period. Scale bars indicate $300 \mu \mathrm{m}$.

mineralization $[29,30]$. The ability to grow and manipulate stem cells derived from the periodontal ligament is of considerable clinical significance, especially in terms of developing novel mechanisms for achieving bone and periodontal tissue regeneration [31]. Previous findings indicated that a subpopulation of PDL cells was induced to osteoblast-like cells which were able to increase ALP activity and form calcified nodules in vitro when cultured in the presence of growth 


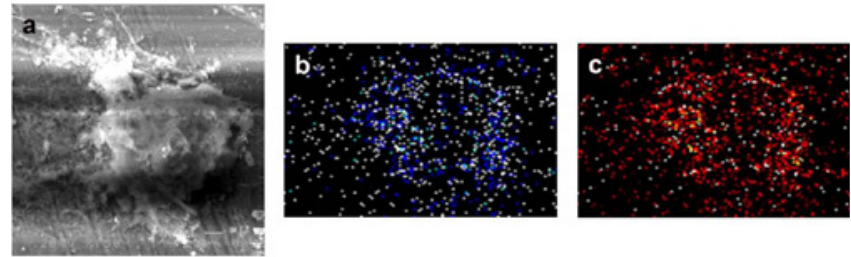

Figure 5: Scanning electron microscopy and energy dispersive $x$-ray mapping of mineralized nodules generated by noni-treated hPDL cells. (A) Scanning electron microscopy revealed heavily colonized cells in a mineralized nodule. (B and $\mathrm{C}$ ) X-ray diffraction analysis showed the point appearances of calcium (blue shade) and phosphorus (orange shade) co-localized in a mineralized nodule after 6 weeks treatment with noni leaf extract, indicating a calcium and phosphorus rich composition of mineralized nodules.

factors such as transforming growth factor-beta (TGF- $\beta$ ) or enamel matrix derivative (EMD) [32-34]. However, results from in vitro, in vivo, and clinical studies with growth factors such as EMD have shown some variability, and also these commercially prepared and purified growth factors remain costly [34]. Therefore, we sought to determine whether a certain natural herb that has been widely and safely used in tropical folk medicines could exhibit osteogenic properties that would be potentially useful for bone and periodontal tissue regeneration.

Noni leaves have been used as an indigenous Polynesian medicine for traditional bone injury treatment $[19,30]$, as well as a topical treatment for wound healing [24]. Some scientific studies have been performed to explore the effect of noni leaves on promoting soft tissue wound healing [24] and mitigating ultraviolet-B (UVB) light-induced injury to the skin [35]. Nevertheless, no controlled studies have been reported on the potential for noni leaves to promote bone or periodontal tissue repair and regeneration. Our study is the first investigation of noni leaf effect on tooth and bone derived cell populations, and we have demonstrated a potent ability for noni leaf extract to induce osteogenic changes in human PDL cells, in vitro. Noni leaf extract increased hPDL cell proliferation and protein synthesis, and additionally promoted increased ALP and mineral nodule formation. The ALP activity and mineral nodule formation is considered as the early and late markers of osteoblast cell function, respectively. In addition, noni leaf extract had a parallel effect on MC3T3-E1 pre-osteoblasts, strongly increasing mineralized matrix formation. Thus, noni leaf extract was capable of promoting differentiation and mineralization by both PDL and preosteoblast cell types.

Cell proliferation remains one of the cornerstone events in tissue regeneration or repair, as there must be sufficient cells to repopulate and begin to repair damages areas. Our in vitro results showed that the hPDL cells treated with noni leaf aqueous extract proliferated at a rate approximately 1.2-1.5 folds higher than controls (Figure 1). This is corresponded to an in vivo result by Nayak et al. [24] on the wound healing effect of ethanol noni leaf extract using a rat model which showed that there were more fibroblasts in the granulation tissue when those rats treated with the noni leaf extract orally. Although our study used the different solvent to extract noni solution, we still demonstrated that the water extract of noni leaves enhanced hPDL proliferation. These results indicate that noni leaf extract has a potential effect on promoting cell proliferation not only in fibroblasts, but in this case also cells originating from PDL tissues. However, the in vivo effect of the water noni extract, and the comparison between the water and ethanol noni extracts will be further studied.

The present study revealed that $2.5 \%(\mathrm{~g} / \mathrm{ml})$ of noni leaf extract which was the highest dose in this study that enhanced hPDL cell proliferation without any toxicity also promoted 4-fold increased ALP activity during the $3^{\text {rd }}$ and the $4^{\text {th }}$ weeks of the experiment (Figure 2 ). The result also showed that timing of peak ALP induction was consistent with mineralized nodule formation after 3 weeks of culture (Figures 2, 3D-F, 3H and I). The change of ALP activity expression of noni-treated hPDL in our study were consistent with the previous study by Aronow et al. [36] and Bellows et al. [37]. The former showed that fetal rat calvaria osteoblasts five weeks in culture expressed alkaline phosphatase was sequentially related to collagen accumulation and mineralization [36]. The latter also showed that ALP activity highly increased before mineralization, and then gradually decreased although mineralization continued in fetal rat calvaria cell cultured in osteogenic condition, indicating alkaline phosphatase plays a crucial role during early differentiation and mineralization of cells with osteoblastic phenotypes [37]. The effect of noni leaf on cell proliferation, ALP activity pattern, and mineralized nodule formation indicates their function to enhance in vitro osteoblast differentiation of hPDL cells.

In the b-GP together with ascorbic acid treated group, the ALP activity of hPDL cells was 2 -fold greater than that of the control group during the $2^{\text {nd }}$ and the $3^{\text {rd }}$ weeks of experiment, and then decreased similarly to the control level (Figure 2). However, the ALP activity of this group was significantly lower than that of the noni treated group, and also no nodule formation and matrix mineralization was observed. This observation corresponded to the previous results that the nodule formation formed by PDL cells was mostly induced in certain conditions such as in the presence of dexamethasone, estradiol and EMD together with TGF- $\beta 1[13,34,38]$. Interestingly, noni leaf treated hPDL cells were able to form mineralized nodules in culture without those inducers, suggesting an attractive property of this natural herb in mineralized tissue regeneration.

The mouse pre-osteoblast line, MC3T3-E1, was exposed to noni leaf extract in order to confirm the osteogenic differentiation and mineralized matrix induction potency of the extract on hPDL cells. Despite untreated MC3T3-E1 cells failed to produce nodules throughout the experimental period, these cells when provided with noni leaf extract or with $\beta$-GP and ascorbic acid exhibited mineralized nodules by 3 weeks (Figures $4 \mathrm{~B}-\mathrm{C}$, and $4 \mathrm{E}-\mathrm{F}$ ) ). In accordance with several prior studies, $\beta$-GP together with ascorbic acid was sufficient to induce MC3T3-E1 to differentiate into osteogenic lineage and form mineralized matrices $[39,40]$ please review ref. no. 35 \& confirm did they use $\beta$-GP with ascorbic acid or not?. Consequently, our data suggest that the noni leaf extract may act as a promising osteogenic inducing material for both mouse pre-osteoblast and hPDL cells.

The noni plant consists of several phytochemical constituents that may function to enhance the osteogenic induction and matrix mineralization. Some bone stimulatory components of noni leaves have been reported, such as ascorbic acid, triterpenes, flavonoid, and others $[24,30]$. Ascorbic acid can promote type I collagen and $\alpha 2 \beta 1$ integrin interaction, resulting in enhancing the expression of ALP activity [41] also, confirm did they use ascorbic acid or not?. This confirms our result that hPDL cells exhibit only a low level of ALP activity when cultured in growth medium without ascorbic acid. Therefore, ascorbic acid in noni treated group may enhance ALP activity via the pathway that induced collagen production and integrin expression in hPDL cultured cells. Subsequently, calcium and phosphorus from noni extract may accumulate in these stimulating collagen fibrils and form matrix mineralization.

The other components of noni such as triterpenes may activate cell proliferation [42], protein synthesis [43], and also ALP activity [44] 
through TGF- $\beta$ signaling pathway [45]. In addition, flavonoids have been shown to promote the osteogenic differentiation of human bone marrow-derived mesenchymal stem cells [46]. Consequently, analysis of some contents in the aqueous extract of Morinda citrifolia will be focused in our future study to confirm its active ingredients.

In conclusion, the present study provides a novel property in herbal medicine of noni leaf aqueous extract to enhance cell proliferation, ALP activity and matrix mineralization of hPDL cells in vitro. These data will support the further development of the noni leaf, a natural herb, as a promising osteoinductive agent for bone and periodontal tissue regeneration.

\section{Acknowledgements}

The authors would like to thank Associate Professor R. Surarit (Mahido University) for the donation of MC3T3-E1 cells in this study. The authors also thank Drs. S. R. Gill, R. Dziak (The State University of New York at Buffalo), and B. Foster (University of Washington) for their reviews of this manuscript. This study was supported by the funding from Faculty of Dentistry, Mahidol University, Bangkok Thailand.

\section{References}

1. Pihlstrom BL, Michalowicz BS, Johnson NW (2005) Periodontal diseases. Lancet 366: 1809-1820.

2. Taba M Jr, Jin Q, Sugai JV, Giannobile WV (2005) Current concepts in periodontal bioengineering. Orthod Craniofac Res 8: 292-302.

3. Shimono M, Ishikawa T, Ishikawa $H$, Matsuzaki H, Hashimoto S, et al. (2003) Regulatory mechanisms of periodontal regeneration. Microsc Res Tech 60 491-502.

4. Isaka J, Ohazama A, Kobayashi M, Nagashima C, Takiguchi T, et al. (2001) Participation of periodontal ligament cells with regeneration of alveolar bone. $J$ Periodontol 72: 314-323.

5. Murakami Y, Kojima T, Nagasawa T, Kobayashi H, Ishikawa I (2003) Nove isolation of alkaline phosphatase-positive subpopulation from periodontal ligament fibroblasts. J Periodontol 74: 780-786.

6. Lekic P, Rojas J, Birek C, Tenenbaum H, McCulloch CA (2001) Phenotypic comparison of periodontal ligament cells in vivo and in vitro. J Periodontal Res 36: 71-79.

7. Ramakrishnan PR, Lin WL, Sodek J, Cho MI (1995) Synthesis of noncollagenous extracellular matrix proteins during development of mineralized nodules by rat periodontal ligament cells in vitro. Calcif Tissue Int 57: 52-59.

8. Chien HH, Lin WL, Cho MI (1999) Expression of TGF-beta isoforms and their receptors during mineralized nodule formation by rat periodontal ligament cells in vitro. J Periodontal Res 34: 301-309.

9. Zhao M, Berry JE, Somerman MJ (2003) Bone morphogenetic protein-2 inhibits differentiation and mineralization of cementoblasts in vitro. J Dent Res 82: 23 27.

10. Ouyang H, McCauley LK, Berry JE, D'Errico JA, Strayhorn CL, et al. (2000) Response of immortalized murine cementoblasts/periodontal ligament cells to parathyroid hormone and parathyroid hormone-related protein in vitro. Arch Oral Biol 45: 293-303.

11. Ohno S, Doi T, Fujimoto K, ljuin C, Tanaka N, et al. (2002) RGD-CAP (betaig-h3) exerts a negative regulatory function on mineralization in the human periodontal ligament. J Dent Res 81: 822-825.

12. Han X, Amar S (2003) IGF-1 signaling enhances cell survival in periodontal ligament fibroblasts vs. gingival fibroblasts. J Dent Res 82: 454-459.

13. Cho MI, Matsuda N, Lin WL, Moshier A, Ramakrishnan PR (1992) In vitro formation of mineralized nodules by periodontal ligament cells from the rat. Calcif Tissue Int 50: 459-467.

14. Nohutcu RM, McCauley LK, Koh AJ, Somerman MJ (1997) Expression of extracellular matrix proteins in human periodontal ligament cells during mineralization in vitro. J Periodontol 68: 320-327

15. Parikh SN (2002) Bone graft substitutes: past, present, future. J Postgrad Med 48: $142-148$

16. Sukumar S, Drízhal I (2008) Bone grafts in periodontal therapy. Acta Medica (Hradec Kralove) 51: 203-207.
17. Matsuda N, Lin WL, Kumar NM, Cho MI, Genco RJ (1992) Mitogenic, chemotactic, and synthetic responses of rat periodontal ligament fibroblastic cells to polypeptide growth factors in vitro. J Periodontol 63: 515-525.

18. Raja S, Byakod G, Pudakalkatti P (2009) Growth factors in periodontal regeneration. Int J Dent Hyg 7: 82-89.

19. Wang MY, West BJ, Jensen CJ, Nowicki D, Su C, et al. (2002) Morinda citrifolia (Noni): a literature review and recent advances in Noni research. Acta Pharmacol Sin 23: 1127-1141.

20. Potterat O, Hamburger M (2007) Morinda citrifolia (Noni) fruit--phytochemistry pharmacology, safety. Planta Med 73: 191-199.

21. Deng S, Palu K, West BJ, Su CX, Zhou BN, et al. (2007) Lipoxygenase inhibitory constituents of the fruits of noni (Morinda citrifolia) collected in Tahiti. J Nat Prod 70: 859-862.

22. Hirazumi A, Furusawa E, Chou SC, Hokama Y (1996) Immunomodulation contributes to the anticancer activity of morinda citrifolia (noni) fruit juice. Proc West Pharmacol Soc 39: 7-9.

23. Akihisa T, Nakamura Y, Tagata M, Tokuda H, Yasukawa K, et al. (2007) Antiinflammatory and anti-tumor-promoting effects of triterpene acids and sterols from the fungus Ganoderma lucidum. Chem Biodivers 4: 224-231.

24. Nayak BS, Sandiford S, Maxwell A (2009) Evaluation of the Wound-healing Activity of Ethanolic Extract of Morinda citrifolia L. Leaf. Evid Based Complement Alternat Med 6: 351-356

25. Gerlier D, Thomasset N (1986) Use of MTT colorimetric assay to measure cell activation. J Immunol Methods 94: 57-63.

26. LOWRY OH, ROBERTS NR, WU ML, HIXON WS, CRAWFORD EJ (1954) The quantitative histochemistry of brain. II. Enzyme measurements. J Biol Chem 207: $19-37$.

27. Thangakumaran S, Sudarsan S, Arun KV, Talwar A, James JR (2009) Osteoblast response (initial adhesion and alkaline phosphatase activity) following exposure to a barrier membrane/enamel matrix derivative combination. Indian J Dent Res 20: 7-12.

28. Bradford MM (1976) A rapid and sensitive method for the quantitation of microgram quantities of protein utilizing the principle of protein-dye binding Anal Biochem 72: 248-254.

29. Chen FM, Jin Y (2010) Periodontal tissue engineering and regeneration: current approaches and expanding opportunities. Tissue Eng Part B Rev 16: 219-255.

30. McClatchey W (2002) From Polynesian healers to health food stores: changing perspectives of Morinda citrifolia (Rubiaceae). Integr Cancer Ther 1: 110-120.

31. Orciani M, Trubiani O, Vignini A, Mattioli-Belmonte M, Di Primio R, et al. (2009) Nitric oxide production during the osteogenic differentiation of human periodontal ligament mesenchymal stem cells. Acta Histochem 111: 15-24.

32. Hobbs HC, Rowe DJ, Johnson PW (1999) Periodontal ligament cells from insulin-dependent diabetics exhibit altered alkaline phosphatase activity in response to growth factors. J Periodontol 70: 736-742.

33. Gestrelius S, Andersson C, Lidström D, Hammarström L, Somerman M (1997) In vitro studies on periodontal ligament cells and enamel matrix derivative. Clin Periodontol 24: 685-692.

34. Rodrigues TL, Marchesan JT, Coletta RD, Novaes AB Jr, Grisi MF, et al. (2007) Effects of enamel matrix derivative and transforming growth factor-beta1 on human periodontal ligament fibroblasts. J Clin Periodontol 34: 514-522.

35. West BJ, Deng S, Palu AK, Jensen CJ (2009) Morinda citrifolia Linn. (Rubiaceae) leaf extracts mitigate UVB-induced erythema. J Nat Med 63: 351 354.

36. Aronow MA, Gerstenfeld LC, Owen TA, Tassinari MS, Stein GS, et al. (1990) Factors that promote progressive development of the osteoblast phenotype in cultured fetal rat calvaria cells. J Cell Physiol 143: 213-221.

37. Bellows CG, Aubin JE, Heersche JN (1991) Initiation and progression of mineralization of bone nodules formed in vitro: the role of alkaline phosphatase and organic phosphate. Bone Miner 14: 27-40.

38. Morishita M, Yamamura T, Shimazu A, Bachchu AH, Iwamoto Y (1999) Estradiol enhances the production of mineralized nodules by human periodontal ligament cells. J Clin Periodontol 26: 748-751.

39. Al-Jallad HF, Nakano Y, Chen JL, McMillan E, Lefebvre C, et al. (2006) Transglutaminase activity regulates osteoblast differentiation and matrix mineralization in MC3T3-E1 osteoblast cultures. Matrix Biol 25: 135-148. 
Citation: Boonanantanasarn K, Janebodin K, Suppakpatana P, Arayapisit T, Chunhabundit P, et al. (2012) Morinda citrifolia Leaf Enhances In Vitro Osteogenic Differentiation and Matrix Mineralization by Human Periodontal Ligament Cells. Dentistry 2:130. doi:10.4172/2161-1122.1000130

40. Quarles LD, Yohay DA, Lever LW, Caton R, Wenstrup RJ (1992) Distinct proliferative and differentiated stages of murine MC3T3-E1 cells in culture: an in vitro model of osteoblast development. J Bone Miner Res 7: 683-692.

41. Chung CH, Golub EE, Forbes E, Tokuoka T, Shapiro IM (1992) Mechanism of action of beta-glycerophosphate on bone cell mineralization. Calcif Tissue Int 51: $305-311$

42. Sant'Ana AC, Marques MM, Barroso TE, Passanezi E, de Rezende ML (2007) Effects of TGF-beta1, PDGF-BB, and IGF-1 on the rate of proliferation and adhesion of a periodontal ligament cell lineage in vitro. J Periodontol 78: 20072017.

43. Mailhot JM, Schuster GS, Garnick JJ, Hanes PJ, Lapp CA, et al. (1995) Human periodontal ligament and gingival fibroblast response to TGF-beta 1 stimulation. J Clin Periodontol 22: 679-685.
44. Dong G, Wu Z, Wang Q, Zhou Y (2001) [Effects of insulin and transforming growth factor-beta on alkaline phosphatase activity and total protein content in human periodontal ligament cells]. Hua Xi Kou Qiang Yi Xue Za Zhi 19 146-148.

45. Suh N, Roberts AB, Birkey Reffey S, Miyazono K, Itoh S, et al. (2003) Synthetic triterpenoids enhance transforming growth factor beta/Smad signaling. Cancer Res 63: 1371-1376.

46. Zhang JF, Li G, Chan CY, Meng CL, Lin MC, et al. (2010) Flavonoids of Herba Epimedii regulate osteogenesis of human mesenchymal stem cells through BMP and Wnt/beta-catenin signaling pathway. Mol Cell Endocrinol 314: 70-74. 